\title{
A NOVEL TRAINING ALTERNATIVE IN ORTHOGNATHIC MANDIBULAR OSTEOTOMY: AIR DRIED CLAY MODEL
}

\author{
ORTOGNATIK MANDIBULA OSTEOTOMISINDE YENI BIR EĞITIM SEÇENEĞi: HAVA \\ KURUTMALI KIL MODELI
}

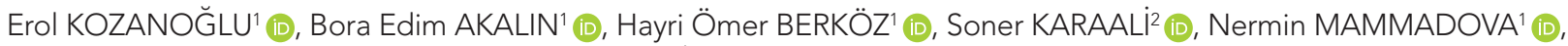 \\ Erman $\mathrm{AK}^{3}$ (D), Ahmet Faruk YÜCEL ${ }^{4}$ (D) Ufuk EMEKLi ${ }^{1}$ (iD \\ ${ }^{1}$ Istanbul University, Istanbul Faculty of Medicine, Department of Plastic, Reconstructive and Aesthetic Surgery, Istanbul, Turkey \\ ${ }^{2}$ Erzincan Binali Yildirim University, Mengücek Gazi Education And Research Hospital, Department of Plastic, Reconstructive and Aesthetic \\ Surgery, Erzincan, Turkey \\ ${ }^{3}$ Istanbul Basaksehir Cam and Sakura City Hospital, Department of Plastic, Reconstructive and Aesthetic Surgery, Istanbul, Turkey \\ ${ }^{4}$ University of Health Science, Kanuni Sultan Süleyman Research and Training Hospital, Department of Plastic, Reconstructive and Aesthetic \\ Surgery, Istanbul, Turkey
}

ORCID IDs of the authors: E.K. 0000-0003-1192-9520; B.E.A. 0000-0002-5654-2082; H.Ö.B. 0000-0001-8063-9995; S.K. 0000-0001-9496-5513; N.M. 0000-0002-5168-5658; E.A. 0000-0002-0203-1842; A.F.Y. 0000-0002-1461-5378; U.E. 0000-0001-9097-5124

Cite this article as: Kozanoglu E, Akalin BE, Berkoz HO, Karaali S, Mammadova N, Ak E, et al. A novel training alternative in orthognathic mandibular osteotomy: air dried clay model. J Ist Faculty Med 2021;84(4):482-7. doi: 10.26650/IUITFD.2021.836789

\section{ABSTRACT}

Objective: Patient safety and low complication rates are indispensable in surgical training and models are among the main educational tools. The aim of this study is to assess the efficiency of a novel model for orthognathic mandibular osteotomy.

Material and Methods: A template and seventeen partial mandibular models (MM-17) were manufactured with air dried clay. The dimensions of the models were feasible for sagittal split ramus osteotomy (SSRO). Model surgery was performed by surgeons with a minimum of three years' experience in orthognathic surgery. Each surgeon operated four separate models and the following data were recorded: corticotomy and SSRO completion time, MM-17 fracture type, similarity value of MM-17 with native mandible, representation value of MM-17, and the training compatibility value of MM-17.

Results: The cost was 0.6 American Dollars. The mean corticotomy time was 126.75 seconds (110-150). Mean cortical resistance similarity value was 8.75 (8-10). The mean SSRO time was 288 seconds (205-401). Sixty percent of the fractures were seen in the outer cortex. The mean medullary resistance similarity value was 5 (4-6) and mean mandibular representation value was 5.25 (4-7). The training compatibility value was 8.25 (7-10).

Conclusion: Air dried clay demonstrated mechanical similarities with bone cortex and it was used for mandibular modelling

\section{ÖZET}

Amaç: Hasta güvenliği ve düşük komplikasyon oranları cerrahi eğitimde olmazsa olmazdır ve modeller temel eğitim yöntemleri arasındadır. Bu çalışmanın amacı, ortognatik mandibula osteotomisinde yeni bir modelin etkinliğini değerlendirmektir.

Gereç ve Yöntemler: Hava kurutmalı kilden bir şablon ve 17 kısmi mandibula modeli (MM-17) üretildi. Modellerin boyutları sagittal split ramus osteotomisine (SSRO) uygundu. Model cerrahisi ortognatik cerrahide en az üç yıllık deneyimi olan dört cerrah tarafından yapıldı. Her cerrah dört ayrı modelde çalıştı ve şu değerler kaydedildi: kortikotomi ve SSRO tamamlanma süresi, MM-17 kırığı ve türü, MM-17'nin mandibula ile benzerlik değeri, temsil değeri ve eğitim uygunluk değeri.

Bulgular: Maliyet 0,6 Amerikan Doları'ydı. Ortalama kortikotomi süresi 127,75 saniyeydi (110-150). Ortalama korteks direnç benzerliği değeri 8,75'ti (8-10). Ortalama SSRO süresi 288 saniyeydi (205-401). Kırıkların yüzde altmışı dış korteksteydi. Ortalama medulla direnç benzerlik değeri 5 (4-6) ve ortalama mandibula temsil değeri 5,25'ti (4-7). Eğitim uygunluk değeri 8,25'ti (7-10).

Sonuç: Hava kurutmalı kil, kemik korteksi ile mekanik benzerlikler göstermektedir ve mandibula modeli üretiminde ilk kez kullanılmıştır. Ayrıca, MM-17 diğer modellerden daha ucuzdur. Kortikotomi ve SSRO tamamlanma süreleri kısadır. Çünkü dissek-

Corresponding author/iletişim kurulacak yazar: erol.kozanoglu@istanbul.edu.tr

Submitted/Başvuru: 06.12.2020 • Revision Requested/Revizyon Talebi: 25.01.2021 •

Last Revision Received/Son Revizyon: 31.01.2021 • Accepted/Kabul: 01.02.2021 • Published Online/Online Yayın: 21.09 .2021 
for the first time. MM-17 cost less than other devices. Corticotomy and SSRO completion times were short due to the lack of dissection and bleeding. Despite its drawbacks in SSRO, MM17 is a versatile and low cost alternative in orthognathic mandibular corticotomy training. High power drill utilization skills may be gained with MM-17 before clinical practice.

Keywords: Air-dried clay, mandible, model surgery, orthognathic surgery, training siyon ve kanama gibi hastaya bağlı etkenler yoktur. SSRO'daki yetersizliklerine rağmen MM-17 ortognatik mandibular kortikotomi eğitiminde çok kullanışlı ve düşük maliyetli bir seçenektir. Yüksek devirli motor kullanımı becerileri klinik uygulama öncesi MM-17 ile edinilebilir.

Anahtar Kelimeler: Eğitim, hava kurutmalı kil, mandibula, model cerrahisi, ortognatik cerrahi

\section{INTRODUCTION}

Orthognathic surgery is one of the main aspects of plastic reconstructive and aesthetic surgery. The management of dentofacial deformities that may be present in dental and facial contours is planned and performed by collaboration between orthodontists and plastic reconstructive and aesthetic surgeons. After appropriate orthodontic treatment, patients may be referred for orthognathic surgery (1). Double jaw surgery may be performed in order to address the deformities in both the maxilla and mandible whereas single jaw surgery is indicated for deformities involving only the mandible (2).

Sagittal split ramus osteotomy, first defined by Obwegeser and Trauner in 1955 is currently the most popular mandibular osteotomy $(2,3)$. Various authors including Hunsuck and Epker modified this osteotomy in order to adapt it to modern practice $(4,5)$.

Due to its anatomical structure, the mandible is suitable to be split through the sagittal plane from both rami. However, such splitting is technically demanding and it requires a level of expertise (1). Orthognathic surgery is not performed equally in quantity throughout the training facilities of Turkey and the number of orthognathic operations is insufficient in some centers (6). All surgical training begins in a clinical manner and novice and inexperienced surgeons, as they go through a learning curve, may perform procedures that result in complications. In order to overcome such shortcomings and to gain expertise, surgical residents must be trained on surgical models. Today, highly technological computer-based planning and simulation is utilized in orthognathic surgery and the training is supported by virtual reality and touch sensitive (haptic) devices $(7,8)$. However, such techniques require both expensive hardware and software and such an infrastructure is lacking in most training facilities.

With the help of a novel, low cost, air- dried clay model, the inexperienced surgeons may improve their skills using high-power surgical devices and progress to a level where they can perform actual surgical procedures.

The aim of this study is to assess the efficiency of this model in basic orthognathic mandibular osteotomy training.

\section{MATERIAL AND METHODS}

The study was presented to the local Ethic Committee in April 2019 and approval was not deemed necessary. In fact, the study was performed neither on humans nor other live subjects.

After the molding process, the air-dried clay (Hardpas, Argiles Bisbal, Spain) can harden without any extra treatment in 24 to 48 hours (9). In order to maintain standardization, an air- dried clay template was manufactured out of an artificial human mandibular model (1020159 [A20], 3B Scientific, USA) (Figure 1). The template was prepared to enable the production of partial mandible models that allowed sagittal split ramus osteotomy.

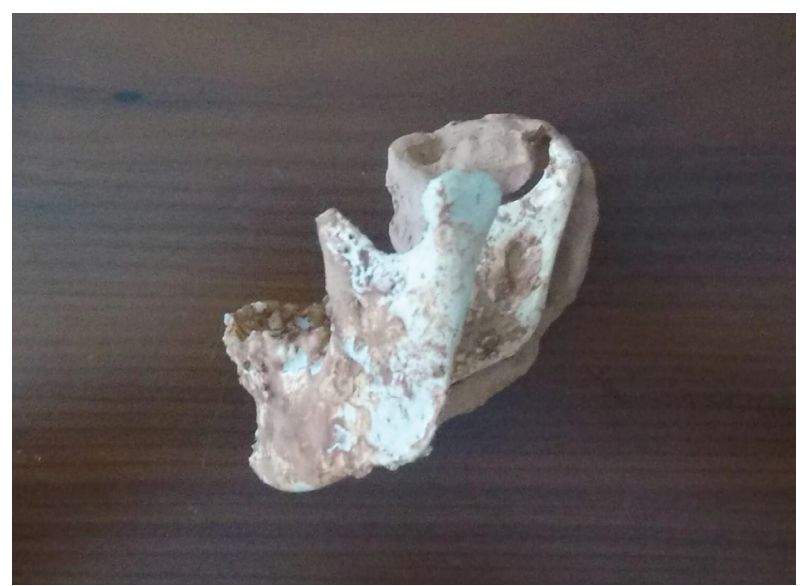

Figure 1: In order to maintain standardization of the model, an air dried clay template was manufactured out of an artificial human mandibular model (1020159 [A20], 3B Scientific, USA)

The template was filled with 75 grams of air dried-clay for each model and partial mandibles were produced. Each model was dried at room temperature for two days and they were weighed at the end of the second day. The mean mass of the models was 68 grams (65-70 grams). A total of 17 models were produced and they were named "Mandibular Model-17" (MM-17) (Figure 2). 


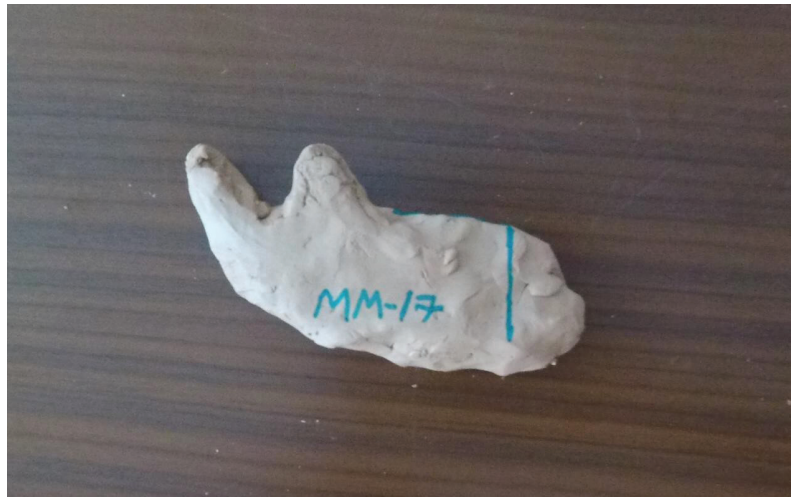

Figure 2: "Mandibular Model-17" (MM-17). The osteotomy lines were marked on the medial, lateral and upper marginal cortices on each model with a surgical marking pen.

Four plastic reconstructive and aesthetic surgeons with at least three years' experience in orthognathic surgery were invited to participate in the study by post. In order to demonstrate the surgical procedure, the first author performed the model surgery while the four surgeons observed. Demonstrative corticotomy and sagittal split ramus osteotomy were performed and the instructions were given to the surgeons. Each participant was given four MM-17's, a high-power drill and a cutting handpiece and they performed model surgeries individually. The participants were asked to operate on four models in order to increase the reliability of the study. The following data were recorded for each model: Corticotomy and SSRO completion time, MM-17 fracture type and time during corticotomy and SSRO, resistance similarity value of MM-17 cortex and medulla with native mandible, mandibular representation value of MM-17, and training compatibility value of MM-17. Resistance similarity and representation values were subjective measurements. A score of " 0 " represented no similarity and " 10 " total similarity and representation between MM-17 and native human mandible. Training compatibility value was another subjective measurement with a similar scale. Zero was total incompatibility whereas ten was total compatibility with orthognathic mandibular osteotomy training. The mean values were calculated and the results were compared. Corticotomies of the entire cortex without fractures were accepted as successful and complete bipartite sagittal split ramus osteotomies without fractures were accepted as successful.

\section{RESULTS}

The human mandibular anatomic model (1020159 [A20], 3B Scientific, USA), the high-power drill and the cutting handpiece belong to our institution and they were not included in the study costs. The only expense of the study was the air-dried clay (Hardpas, Argiles Bisbal, Spain) that was used for the production of both the template and the model. After the production of two templates and seventeen $\mathrm{MM}-17$ 's, the cost of a single MM-17 was calculated as 0.6 American Dollars.

The results are listed in Table 1. All corticotomies were completed successfully (16/16) and no fractures were observed during the corticotomies (Figure 3). Mean corticotomy completion time was 127.75 seconds (110-150 seconds). Mean cortical resistance similarity value was 8.75 (8-10). Only three sagittal split ramus osteotomies were completed successfully (3/16) (19\%) (Figure 4). The

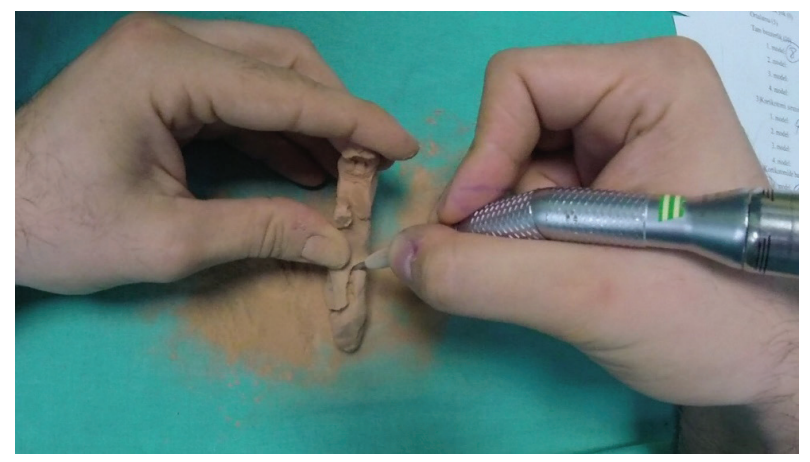

Figure 3: A successful MM-17 corticotomy.

Table 1: The mean values and results obtained from each surgeon after the model surgeries

\begin{tabular}{lccccccc}
\hline & CCT (seconds) & CSV & SSROCT (seconds) & SSROSV & SSRO failure & RV & TCV \\
\hline Surgeon 1 & 110 & 8 & 401 & 5 & 3 & 5 & 9 \\
Surgeon 2 & 150 & 10 & 0 & 5 & 4 & 4 & 7 \\
Surgeon 3 & 116 & 8 & 259 & 6 & 3 & 7 & 10 \\
Surgeon 4 & 131 & 9 & 205 & 4 & 3 & 5 & 7 \\
Mean & 126,75 & 8,75 & 288 & 5 & 13 failures (81\%) & 5,25 & 8,25 \\
& & & & & 3 success (19\%) & & \\
\hline
\end{tabular}

CCT: Corticotomy completion time; CSV: Corticotomy similarity value; SSROCT: Sagittal split ramus osteotomy completion time; SSROSV: Sagittal split ramus osteotomy similarity value; SSRO failure: Sagittal split ramus osteotomy failure; RV: Representation value of MM-17; TCV: Training compatibility value of MM-17. 


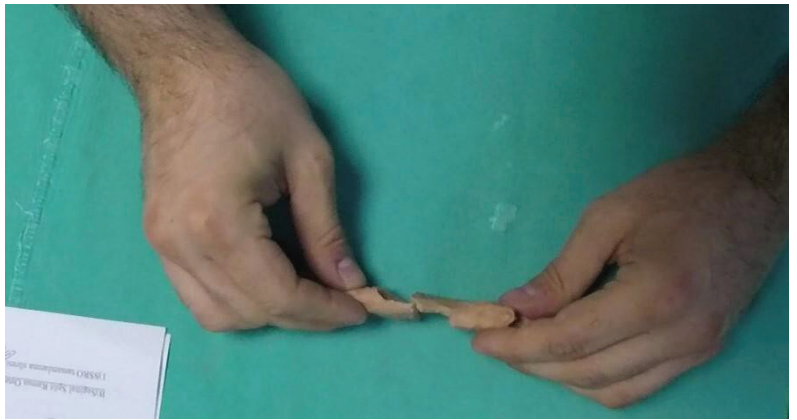

Figure 4: A successful MM-17 sagittal split ramus osteotomy.

outer cortex was affected in sixty percent of the fractures and the inner cortex was affected in forty percent of the fractures. Three successful SSRO's were completed in a mean time of 288 seconds (205-401 seconds). Mean medullary resistance similarity value was 5 (4-6). Mean mandibular representation value of MM-17 was 5.25 (4-7). Mean value of compatibility with orthognathic mandibular osteotomy training was 8.25 (7-10).

No technical problems were observed in either the highpower drills or the handpieces (Figure 5).

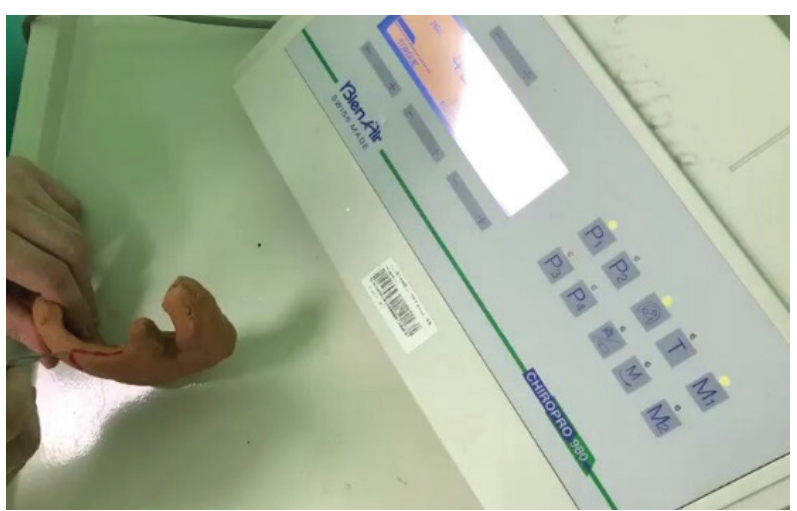

Figure 5: A high power drill that was utilized in the model surgery.

\section{DISCUSSION}

Structural deformities of the maxilla and the mandible may cause dental misalignment, malocclusion and alterations in facial appearance. Such deformities may be corrected with orthognathic surgery, ameliorating both form and function (2).

In sagittal split ramus osteotomy, the osteotomy of the medial cortex of the ramus is performed above the lingula and the lateral corticotomy is performed between the first and the second molar teeth. Finally, the upper margin of the ramus is corticotomized in order to connect the medial and the lateral corticotomy lines. After the corticotomies, a full-thickness osteotomy is performed in order to split the ramus into condylar and alveolar fragments. At the end of bilateral sagittal split ramus osteotomies, two condylar and one alveolar fragments are formed and the alveolar fragment may be positioned in three planes according to the orthodontic plan (1-5).

Sagittal split ramus osteotomy (SSRO) is prone to complications including unfavorable fractures, unfavorable splits, inferior alveolar and facial nerve injuries and internal maxillary artery injuries (10). The avoidance and management of these complications require technical experience in SSRO.

Although there are numerous plastic reconstructive and aesthetic surgery training institutions in Turkey, orthognathic surgery training is still limited and there are vast differences between centers (6). The main reasons for this limitation are requirements of coordination with orthodontics clinics and of specialized surgical instruments (2). In modern surgical training of the residents, maximal patient safety and minimal complication rates are basic principles (11). However, due to the aforementioned limitations, most residents can not have sufficient orthognathic surgical training in line with these principles (6). In order to maintain patient safety with minimal complications, orthognathic surgical models may be utilized.

Residents of all surgical fields may gain relevant skills with surgical models and they may support their theoretical knowledge before clinical practice. Palter et al. compared training results with low cost artificial models for fascial repair and the residents who had practiced with the models had a better surgical ability and understanding of the surgical procedure in the operating room (11). Easily reproducible and low cost models such as MM-17 may yield similar results in orthognathic surgery training. Plastic Reconstructive and Aesthetic surgery residents may gain relevant skills with MM-17 and continue clinical practice with more safety and fewer complications.

Cadavers and various artificial materials are regarded as the gold standard in all surgical training models (8). However, they may not be feasible for every training institution due to cost and availability. Three-dimensional virtual and solid models can be manufactured using thin sliced maxillofacial computed tomographs and model surgery can be practiced on such models (7). Currently, virtual reality is a popular alternative in orthodontic planning and orthognathic surgery training and it may be supported by touch-sensitive haptic simulators (12). With such simulators, the resident may visualize the relevant anatomic area with three-dimensional, real time detail through virtual reality and hand-held or wearable haptic devices may reflect the alterations in the target tissue $(8,13,14)$. All such surgical models require specialized computer software, three-dimensional printers 
and haptic receptors with very high costs. In contrast to these current and expensive models, the MM-17 cost less than an American dollar. Also, real time instrumental experience and skills may be gained during the model surgery with $\mathrm{MM}-17$.

Various materials may be utilized in the production of sagittal split ramus osteotomy (SSRO) artificial models. Baccarin et al. compared three different materials in a model study that evaluated osseous fixation after SSRO: plastic, polyamide and polyurethane (15). None of the materials were biomechanically equivalent to the human mandible in aspects of elasticity, texture and load bearing capacity. All models were found to be relevant only for the simulatory training and for the preparation for clinical practice (15). The ideal material has not been found for the production of mandibular models. The air-dried clay of MM-17, which was utilized for the first time, needs to be evaluated objectively with biomechanical studies.

The literature has a limited number of studies on surgical models produced with air-dried clay. Kazum et al. designed a bone drilling model for orthopaedics surgery residents (16). In this design, the air-dried clay layer was attached to the posterior cortex of an artificial bone and the residents were asked to drill holes through the artificial bone. After the drilling process, the air dried-clay layer was checked for evidence of overdrilling through the posterior cortex and into this clay layer. Kazum et al. designed this study with respect to the similarity between the resistance and texture of the artificial bone cortex and the air-dried clay (16). In accordance with this study, successful corticotomies were performed on each MM-17 and the participants of the study evaluated the MM-17 cortex with a mean similarity value of 8.75 out of 10. According to the similar results of these two studies, air- dried clay represented the bone cortex effectively.

The corticotomy and sagittal split ramus osteotomy completion times were shorter than live surgery. These differences were due to the lack of soft tissue dissection, retraction, bleeding and assistance during the model surgery. Bleeding and the control of bleeding are major factors that prolong operative times. The SSRO success of MM-17 was 19\% and numerous osteotomy failures, including outer cortical fractures, were seen during the model surgery. The main reason for these failures was the absence of osseous medulla in the uniformly constituted cortex MM-17 models. Therefore, the participants did not report the same procedural success for SSRO as the corticotomy and the SSRO similarity value was 5 out of 10. Also, the mandibular representation value of $\mathrm{MM}-17$, measured at 5.25 out of 10, was lower because of the absence of osseous medulla. This important detail is a limitation of this surgical model. Also, the ramus of the model is slightly thicker than normal mandible. Due to this limitation, the model may be regarded as a simple tool for beginners. New designs may be required for completing the learning curve of inexperienced surgeons.

Mandibular corticotomies, which are performed with specialized instruments such as high-power drills, are the first steps of a successful orthognathic surgery. Experience and skills with such instruments should be gained before operating on real patients. Four experienced orthognathic surgeons evaluated the training compatibility value of $\mathrm{MM}-17$, reporting a mean of 8.25 points out of 10. Thus, the learning curve of corticotomy with specialized instruments may be completed on MM-17 models.

Not every resident has the opportunity to train in an orthognathic surgery performing clinic, and clinical practice may not be possible for every surgeon. MM-17 may address the basic needs of a novice orthognathic surgery resident with its low cost and versatility in mandibular corticotomy.

Peer Review: Externally peer-reviewed.

Author Contributions: Conception/Design of Study- E.K., B.E.A., H.Ö.B., S.K., N.M., E.A., A.F.Y., U.E.; Data AcquisitionE.K., B.E.A., H.Ö.B., S.K., N.M., E.A., A.F.Y., U.E.; Data Analysis/ Interpretation- E.K., B.E.A., H.Ö.B., S.K., N.M., E.A., A.F.Y., U.E.; Drafting Manuscript- E.K., B.E.A., H.Ö.B., S.K., N.M., E.A., A.F.Y., U.E.; Critical Revision of Manuscript- E.K., B.E.A., H.Ö.B., S.K., N.M., E.A., A.F.Y., U.E.; Final Approval and Accountability- E.K., B.E.A., H.Ö.B., S.K., N.M., E.A., A.F.Y., U.E.

Conflict of Interest: Authors declared no conflict of interest.

Financial Disclosure: Authors declared no financial support.

Hakem Değerlendirmesi: Dış bağımsız.

Yazar Katkıları: Çalışma Konsepti/Tasarım- E.K., B.E.A., H.Ö.B., S.K., N.M., E.A., A.F.Y., U.E.; Veri Toplama- E.K., B.E.A., H.Ö.B., S.K., N.M., E.A., A.F.Y., U.E.; Veri Analizi/Yorumlama- E.K., B.E.A., H.Ö.B., S.K., N.M., E.A., A.F.Y., U.E.; Yazı Taslağı- E.K., B.E.A., H.Ö.B., S.K., N.M., E.A., A.F.Y., U.E.; İçeriğin Eleştirel İncelemesi- E.K., B.E.A., H.Ö.B., S.K., N.M., E.A., A.F.Y., U.E.; Son Onay ve Sorumluluk- E.K., B.E.A., H.Ö.B., S.K., N.M., E.A., A.F.Y., U.E.

Çıkar Çatışması: Yazarlar çıkar çatışması beyan etmemişlerdir.

Finansal Destek: Yazarlar finansal destek beyan etmemişlerdir.

\section{REFERENCES}

1. Reyneke JP, Ferretti C. The bilateral sagittal split mandibular ramus osteotomy. Atlas of the oral and maxillofacial surgery clinics of North America 2016;24(1):27-36. [CrossRef]

2. Reyneke J. In essential in orthognathic surgery [Chapter 4]. Chicago: Quintessence 2003:171-5. 
3. Obwegeser H. Zur Operationstechnik bei der progenie und anderer unterkieferanomalien. Dtsch, Z Mund Kieferheilk 1955;23:1-26.

4. Hunsuck E. A modified intraoral sagittal splitting technique for correction of mandibular prognathism. J Oral Surg 1968;26:249-52.

5. Epker BN. Modifications in the sagittal osteotomy of the mandible. J Oral Surg 1977;35(2):157-9.

6. Yuce $E$, Komerik N. Oral maxillofacial training: opinions of trainees and specialists in Turkey. Journal of Contemporary Medi cal Education 2015;3(1):25-30. [CrossRef]

7. Lutz JC, Hostettler A, Agnus V, Nicolau S, George D, Soler L, et al. A new software suite in orthognathic surgery: patient specific modeling, simulation and navigation. Surgical innovation 2019;26(1):5-20. [CrossRef]

8. Chen $\mathrm{X}, \mathrm{Hu} \mathrm{J}$. A review of haptic simulator for oral and maxillofacial surgery based on virtual reality. Expert Review of Medical Devices 2018;15(6):435-44. [CrossRef]

9. Website AB. [cited 2019 14.05]. Available from: http:// argilesbisbal.com/en/portfolio/hardpast/

10. Mehra P, Castro V, Freitas RZ, Wolford LM. Complications of the mandibular sagittal split ramus osteotomy associated with the presence or absence of third molars. Journal of oral and maxillofacial surgery 2001;59(8):854-8. [CrossRef]
11. Palter VN, Grantcharov T, Harvey A, MacRae HM. Ex vivo technical skills training transfers to the operating room and enhances cognitive learning: a randomized controlled trial. Annals of surgery 2011;253(5):886-9. [CrossRef]

12. Ureturk EU, Apaydin A. Does fixation method affect temporomandibular joints after mandibular advancement? Journal of Cranio-Maxillofacial Surgery 2018;46(6):923-31. [CrossRef]

13. Sohmura T, Hojo H, Nakajima M, Wakabayashi K, Nagao M, lida $\mathrm{S}$, et al. Prototype of simulation of orthognathic surgery using a virtual reality haptic device. International journal of oral and maxillofacial surgery 2004;33(8):740-50. [CrossRef]

14. Maliha SG, Diaz-Siso JR, Plana NM, Torroni A, Flores RL. Haptic, physical, and web-based simulators: Are they underused in maxillofacial surgery training? Journal of Oral and Maxillofacial Surgery 2018;76(11):2424 e1-. e11. [CrossRef]

15. Baccarin L, Casarin RCV, Lopes-da-Silva J, Passeri L. Analysis of mandibular test specimens used to assess a bone fixation system. Craniomaxillofacial trauma\&reconstruction 2015;8(3):171-8. [CrossRef]

16. Kazum E, Dolkart O, Rosenthal Y, Sherman H, Amar E, Salai $M$, et al. A simple and low-cost drilling simulator for training plunging distance among orthopedic surgery residents. Journal of surgical education 2019;76(1):281-5. [CrossRef] 